\title{
Examining the Correlation between University Students' Perceived Teacher Immediacy and their Motivation
}

\author{
Dr. Tariq Hussain*, Dr. Asmaa Azeem**, Nisar Abid*** \\ *Assistant Professor, Institute of Education and Research, University of the Punjab, Lahore. Email: tariqedu71@yahoo.com \\ **Assistant Professor, University of Management \& Technology, Lahore. Email: asmaa.nouman@umt.edu.pk \\ *** Instructor Education, Virtual University of Pakistan, Email: nisar.abid@vu.edu,pk
}

\begin{abstract}
This descriptive correlational study was intended to explore the relationship between university students' perceived teacher immediacy and their motivation. 800 students were selected from eight different universities of district Lahore through a multi-stage stratified random sampling method. Out of the selected, 726 participants responded on adapted Verbal Immediacy Behaviors (VIB), Revised Nonverbal Immediacy Measures (RNIM), and Students Motivation Scale (SMS). Independent sample t-tests' results exhibited no significant gender-based or sector-wise difference in perceived teacher immediacy and motivation level of students. However, the correlational evidence showed a strong correlation between verbal, nonverbal, overall teacher immediacy, and student motivation. Results suggest that teacher immediacy functions as a means of enhancing the motivation of a student, based on this fact, the researchers suggest that content to promote teacher immediacy should be added in teacher education curricula.
\end{abstract}

Keywords:

Teacher Immediacy, Verbal Immediacy, Nonverbal Immediacy, Student Motivation.

Article Received: 18 October 2020, Revised: 3 November 2020, Accepted: 24 December 2020

\section{INTRODUCTION}

During the past four decades, research in the area of teacher immediacy gained more attention than other forms of instructional communication. Originally, the concept of teacher immediacy was introduced as communication behaviors that "improve closeness and nonverbal contact with another" (Mehrabian, 1968, p. 203). Mehrabian implied that approach-avoidance theory formed the basis of this concept; "people concern what they like and dislike" (Mehrabian, 1981, p. 22). Mehrabian (1971) also categorized the behaviors that involve decreasing the perceived psychological or physical detachment between communicators into verbal and nonverbal immediacy behaviors (Christophel, 1990; Gorham, 1988; Hines et al., 1985; Richmond et al., 1987). Numerous earlier studies concluded that nonverbal communication, perceived as immediacy behaviors, affects the teaching-learning process (Breed, 1971; Kleinfeld, 1973; Woolfolk, 1978). Andersen's (1978) study “examined the correlation in teachers' nonverbal immediacy behaviors and students' learning outcomes" paving the path for further research into immediacy (Andersen, 1979). This also prompted the systematic exploration of teacher immediacy and student's learning outcomes.

Mehrabian (1981) argued that immediacy behaviors are associated with motivation. Several studies support his argument and demonstrate that immediacy variables are helpful in enhancing students' motivation, and cognitive learning (Butland \& Beebe, 1992; Christensen et al., 1995; Edwards \& Edwards, 2001; Powell \& Harville, 1990; Rodriguez et al., 1996). Since, Brophy (2004) concluded that student motivation is one of the critical components to their success, researchers and stakeholders in the education infrastructure need to realize the correlation between immediacy behaviors and students' motivation to be able to exploit it for better academic results.

In their research, Pogue and AhYun (2006) found teachers' nonverbal immediacy to be highly related to students' motivation. Similarly, Velez and Cano (2008) found immediacy behaviors to 
have a strong relationship with motivation. Moreover, Ozmen (2011) concluded that teaching effectiveness is substantially positively influenced by teachers' nonverbal immediacy behaviors. Additionally, Fallah (2014) discovered positive paths from motivation to willingness, from motivation to self-confidence, from immediacy to motivation. Recently, Paul et al. (2019) determined that teaching effectiveness is significantly influenced by nonverbal immediacy behaviors. Furthermore, Fernandes (2019) found a significant association between teacher communication and student motivation.

It is inferred from the pieces of literature discussed above that teacher immediacy behaviors are positively correlated with students' learning, while, this relationship is not direct for all types of learning. Existing research studies on the construct of teachers' immediacy and students' motivation are representatives of a particular geographic locale therefore, the present study is designed to examine the correlation in university students' perceived teacher immediacy and their motivation specifically in the context of Pakistan.

\section{Research Objective \& Hypotheses}

1. To compare gender-based and sector-wise differences in university students' perception of teacher immediacy and motivation.

2. To explore the relationship between students' perceived teacher immediacy and motivation.

$\mathrm{H}_{\mathrm{o} 1}$ : There is no gender-based significant difference in university students' perception of teacher immediacy and motivation.

$\mathrm{H}_{\mathrm{o} 2}$ : There is no sector-wise significant difference in university students' perception of teacher immediacy and motivation.

$\mathrm{H}_{03}$ : There is no relationship between students' perceived teacher immediacy and motivation.

\section{Theoretical Framework}

Mehrabian (1968) purposed the communication theory that provided the ground for the concept of immediacy behaviors. He believed that a message is conveyed through two types of communication i.e., implicit and explicit. The implicit style of communication is used to express feelings and exhibit emotions while the explicit style of communication is used to transfer content (Butland \& Beebe, 1992). Mehrabian (1981) believed that implicit communication, as the expressions of feelings and exhibitions of emotions, is beyond the information that is conveyed through speech. In essence, verbal messages are explicit whereas nonverbal messages are implicit styles of communication that have been unified under the concept of immediacy (Witt et al., 2004). Later in his career, Mehrabian (1981) stated that immediacy behaviors have an association with the motivational trait $(\mathrm{p}, 22)$.

Mehrabian (1981) and following researchers (Christophel, 1990; Gorham, 1988; Hines et al., 1985; Richmond et al., 1987) divided immediacy's construct into two subcategories of communication (verbal and nonverbal). Christophel (1990) and Gorham (1988) claimed that immediacy variables are responsible to enhance students' motivation as well as cognitive learning (e.g., Butland \& Beebe, 1992; Christensen et al., 1995; Edwards \& Edwards, 2001; Menzel \& Carrell, 1999; Plax et al., 1986; Powell \& Harville, 1990; Rodriguez et al., 1996). Similarly, students' motivation is recognized as a critical component of academic success (Brophy, 2004; Deci et al., 1991). Teachers need to adopt appropriate immediacy behaviors so that they may improve students' motivation (Brophy, 2004; Wigfield \& Eccles, 2000) because if they can increase students' interest in learning then students may acquire more knowledge consciously (Hofer, 2006).

\section{RELATED LITERATURE}

After the introduction of the concept of immediacy in the field of communication research by Mehrabian (1968), numerous successive investigators explored the role of immediacy in the teaching-learning process. However, Andersen et al., (1979) were the pioneer investigators who attempted to determine teacher immediacy by introducing the relevant instruments to measure it. Investigators explored teacher immediacy as a successful and latent predictor of students' behavioral commitment and cognitive learning. Afterward, Richmond et al. (1987) discovered a significant correlation between teachers' 
immediacy behaviors and students' cognitive learning. Meanwhile, Gorham (1988) only examined the various verbal immediacy behaviors of teachers that were considered helpful to enhance students' learning. Later, Christophel (1990) designed a study to scrutinize the association of teacher immediacy and student motivation. It was found that immediacy affected students' motivation level, and thus led to increased learning. Almost a decade later, Frymier and Houser (2000) found a strong positive correlation between teachers' immediacy, as perceived by students; motivation; and learning.

Witt et al., (2004) carried out a metaanalytical review of 81 studies regarding correlation in teachers' verbal/nonverbal (or both) immediacy and students' learning outcomes. The collective results exhibited a significant correlation between teachers' immediacy and students' cognitive learning. Afterward, Allen et al. (2006) also designed a meta-analysis study on the role of teacher immediacy behaviors as a motivational factor in students' cognitive and affective learning. They constructed a model that suggested that perceived high levels of teacher immediacy behaviors perform as a means of enhancing students' motivation, and students' high motivation improves cognitive learning. Moreover, Pogue and AhYun (2006) assumed that teachers' nonverbal immediacy and credibility work together to influence students' motivation and effective learning. On the other hand, Velez and Cano (2008) scrutinized the correlation between teacher immediacy behaviors and students' motivation and found verbal immediacy behaviors to have a strong connection with motivation, while nonverbal immediacy behaviors showed a moderate association with students' motivation.

Ozmen (2011) explored correlation in prospective teachers' nonverbal immediacy behaviors and their effective teaching in the English language. He concluded that teaching effectiveness is substantially positively influenced by teachers' nonverbal immediacy behaviors. Fallah (2014) used a structural equation modeling approach to examine the possible associations among willingness to communicate, students' shyness, self-confidence, motivation, and teacher immediacy. He discovered considerable positive paths from self-confidence and motivation to willingness, from motivation to self-confidence, from immediacy to motivation. Whereas, negative paths found from teacher immediacy to shyness, and from shyness to self-confidence and motivation. Paul et al. (2019) analyzed the impact of teachers' nonverbal immediacy behaviors and their teaching effectiveness and found no significant difference in male and female teachers' immediacy behaviors. Moreover, they found teaching effectiveness was significantly influenced by nonverbal immediacy behaviors. Fernandes (2019) investigated teachers' communication, credibility, and its correlation with students' motivation, and academic achievement. Results indicated a significant association between teachers' communication and credibility, and between teachers' communication and students' motivation. However, the researcher found no significant relationship between teachers' communication and students' academic achievement, and no significant relationship between students' motivation and academic achievement.

\section{METHOD}

A quantitative approach with descriptive correlational research design was adopted to explore the relationship between teacher immediacy and students' motivation. A multistage, stratified random sampling technique was used to select 1200 students from the private and public sector universities of district Lahore. At the first stage, four universities were selected from each sector through a disproportionate stratified random sampling technique. Secondly, five classes from two-year M. A. Education and four-year BS Education programs were selected randomly from each selected university. Lastly, 30 students were selected randomly from each selected class. The graphical representation of the sample is given in figure 1. 


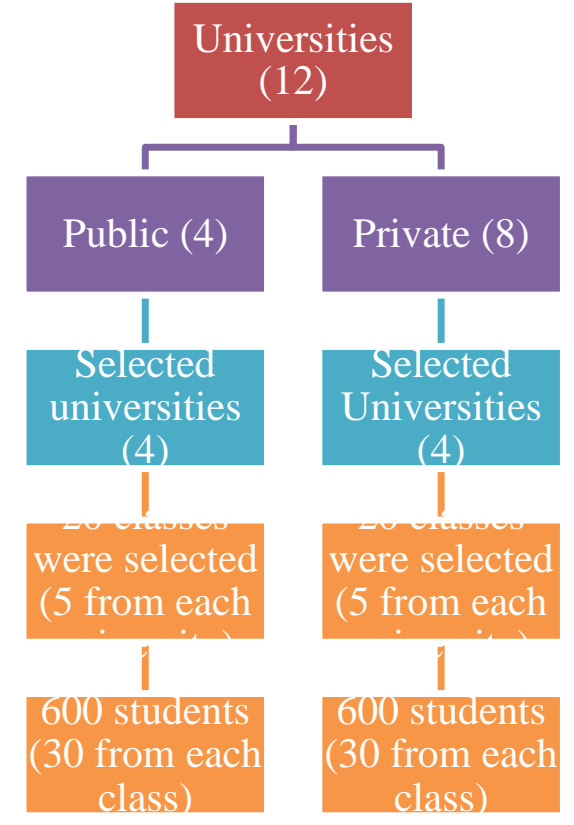

Figure 1: Sample of the Study

\section{INSTRUMENTS}

Three instruments were adapted to collect data:

1. Verbal Immediacy Behaviours (VIB), developed by Gorham in 1998

2. Revised Nonverbal Immediacy Measures (RNIM), developed by McCroskey and his colleagues in 1996

3. Students Motivation Scale (SMS), developed by Rubin and his colleagues in 1994

Psychometric properties of each instrument were evaluated to ensure validity as well as reliability. Furthermore, five educational and assessment experts ensured the structure and usability of these instruments in the local context.

The questionnaire was administered to 250 randomly selected students from the population group for pilot testing to ensure the reliability (internal consistency and composite reliability) of these instruments. A total of eight items were deleted, as $\lambda<.5$, to improve the reliability. Consequently, the Cronbach's alpha (internal consistency and composite reliability) values for the revised instruments ranged from .823 to .876 which indicates good reliability to measure teacher immediacy and students' motivation. The final version of the adapted VIB consisted of nine items, RNIM contained eight items, and SMS comprised of eight items. Each item was constructed on a fivepoint, Likert-type scale, with values ranging from
1-5. The researchers acquired consent from the relevant authorities to administer the study instruments. Out of the intended 1200, 1031 participants gave responses to these instruments.

\section{RESULTS}

Statistical Package for Social Sciences (SPSS-21) was used to test the hypotheses of the present study. The researchers applied independent sample $t$-tests and Pearson's $r$ test.

Ho1: There is no gender-based significant difference in university students' perception of teacher immediacy and motivation.

Table 1

Gender-based Comparison of Students' Perceptions about Teachers Immediacy

\begin{tabular}{|c|c|c|c|c|c|c|c|}
\hline & \multicolumn{2}{|c|}{$\begin{array}{l}\text { Male } \\
\text { (372) }\end{array}$} & \multicolumn{2}{|c|}{$\begin{array}{l}\text { Female } \\
(659)\end{array}$} & \multirow[t]{2}{*}{$T$} & \multirow[t]{2}{*}{$P$} & \multirow[t]{2}{*}{$d$} \\
\hline & $M$ & $S D$ & $M$ & $S D$ & & & \\
\hline Verbal & 30. & 4.8 & 29. & 5.0 & .4 & .1 & .1 \\
\hline $\begin{array}{l}\text { Immedi } \\
\text { acy }\end{array}$ & 06 & 33 & 26 & 85 & 78 & 64 & 61 \\
\hline Nonver & 26. & 4.2 & 26. & 4.5 & .4 & .1 & .1 \\
\hline $\begin{array}{l}\text { bal } \\
\text { Immedi } \\
\text { acy }\end{array}$ & 72 & 96 & 08 & 24 & 25 & 45 & 45 \\
\hline Overall & 56. & 9.1 & 55. & 9.6 & .9 & .3 & .1 \\
\hline $\begin{array}{l}\text { Teache } \\
\text { r } \\
\text { Immedi } \\
\text { acy }\end{array}$ & 78 & 29 & 34 & 05 & 03 & 11 & 54 \\
\hline Student & 27. & 5.1 & 28. & 5.1 & .8 & .4 & .1 \\
\hline $\begin{array}{l}\text { Motiva } \\
\text { tion }\end{array}$ & 84 & 76 & 64 & 52 & 69 & 87 & 55 \\
\hline
\end{tabular}

Note: $\mathrm{N}=1031 ; d=$ Cohen's $d$; and $*=p<.05$.

Results indicate that teachers' verbal, nonverbal, and overall immediacy was perceived as slightly higher by male respondents than females. However female students are slightly more motivated than male students. Table 1 also exhibits that there was no gender-based significant difference in university students' perceived teachers' verbal, nonverbal, and overall immediacy as well as their own motivation level as $t(1029)=.478, p=.164$; $t(1029)=.425, p=.144 ; t(1029)=.903, p=.311$; $t(1029)=.869, p=.487$, respectively. Furthermore, Cohen's $d$ values show no gender-based relation of students' perception of teacher immediacy, and 
motivation level as $d$ ranges from .145 to .161. Hence, the null hypothesis "there is no genderbased significant difference in university students' perception of teacher immediacy and motivation" was accepted as the $p$ was greater than .05 .

$\mathbf{H}_{\mathbf{0} 2}$ : There is no sector-wise significant difference in university students' perception of teacher immediacy and motivation.

Table 2

Sector-wise Comparison of Students' Perceptions of Teacher Immediacy

\begin{tabular}{|c|c|c|c|c|c|c|c|}
\hline \multirow[t]{2}{*}{$\begin{array}{l}\text { Variabl } \\
\text { es }\end{array}$} & \multicolumn{2}{|c|}{$\begin{array}{l}\text { Public } \\
\text { (564) }\end{array}$} & \multicolumn{2}{|c|}{$\begin{array}{l}\text { Private } \\
\text { (467) }\end{array}$} & \multirow[t]{2}{*}{$t$} & \multirow[t]{2}{*}{$p$} & \multirow[t]{2}{*}{$d$} \\
\hline & $M$ & $S D$ & $M$ & $S D$ & & & \\
\hline Verbal & 29. & 5.0 & 29. & 5.0 & - & .1 & .0 \\
\hline $\begin{array}{l}\text { Immed } \\
\text { iacy }\end{array}$ & 43 & 22 & 71 & 76 & $\begin{array}{l}.27 \\
9\end{array}$ & 90 & 55 \\
\hline Nonver & 26. & 4.4 & 26. & 4.5 & - & .1 & .0 \\
\hline $\begin{array}{l}\text { bal } \\
\text { Immed } \\
\text { iacy }\end{array}$ & 16 & 64 & 43 & 12 & $\begin{array}{l}.24 \\
8\end{array}$ & 69 & 60 \\
\hline Overall & 55. & 9.4 & 56. & 9.5 & - & .3 & .0 \\
\hline Teache & 59 & 86 & 14 & 88 & $\begin{array}{l}.52 \\
7\end{array}$ & 59 & 58 \\
\hline
\end{tabular}

Immed

iacy

$\begin{array}{llllllll}\text { Student } & 28 . & 5.2 & 27 . & 4.9 & 1.1 & .0 & .1\end{array}$

$\begin{array}{llllllll}\text { Motiva } & 48 & 88 & 84 & 92 & 06 & 82 & 24\end{array}$

tion

Note: $N=1031 ; d=$ Cohen's $d$; and $*=p<.05$.

The table above shows that the students enrolled in private sector universities perceived teachers' verbal, nonverbal, and overall immediacy to be slightly higher than their counterparts enrolled in public sector universities. Conversely, students enrolled in public sector universities are slightly more motivated as compared to students enrolled in private sector universities. Also, no sector-wise significant difference was found in university students' perceived teachers' verbal, nonverbal, and overall immediacy, and students' own motivation level as $t(1029)=.279, p=.190$; $t(1029)=.248, p=.169 ; t(1029)=.527, p=.359$; $t(1029)=1.106, p=.082$, respectively. Moreover, Cohen's $d$ values exhibit no effect of students' perception of teachers' immediacy on their motivation level when examined in the context of sectors, as $d$ ranges from .055 to .124 . Hence, the null hypothesis "there is no sector-wise significant difference in university students' perception of teacher immediacy and motivation" was accepted as $p>.05$.

Ho3: There is no relationship between students' perceived teacher immediacy and motivation.

Table 3

Correlation between Teacher Immediacy and Students' Motivation

\begin{tabular}{|c|c|c|c|c|}
\hline & $\begin{array}{l}\text { Verbal } \\
\text { Immedi } \\
\text { acy }\end{array}$ & $\begin{array}{l}\text { Nonver } \\
\text { bal } \\
\text { Immedi } \\
\text { acy }\end{array}$ & $\begin{array}{l}\text { Overall } \\
\text { Teache } \\
\mathrm{r} \\
\text { Immedi } \\
\text { acy }\end{array}$ & $\begin{array}{l}\text { Student } \\
\text { Motiva } \\
\text { tion }\end{array}$ \\
\hline $\begin{array}{l}\text { Verbal } \\
\text { Immedi } \\
\text { acy }\end{array}$ & 1 & & & \\
\hline $\begin{array}{l}\text { Nonver } \\
\text { bal } \\
\text { Immedi } \\
\text { acy }\end{array}$ & $.721 * *$ & 1 & & \\
\hline $\begin{array}{l}\text { Overall } \\
\text { Teache }\end{array}$ & $.718 * *$ & $.752 * *$ & 1 & \\
\hline $\begin{array}{l}\mathrm{r} \\
\text { Immedi } \\
\text { acy }\end{array}$ & & & & \\
\hline $\begin{array}{l}\text { Student } \\
\text { Motivat } \\
\text { ion }\end{array}$ & $.626 * *$ & $.677 * *$ & $.723 * *$ & 1 \\
\hline
\end{tabular}

Note: $* *=$ Correlation is significant at the .01 level

Correlation matrix results describe that teacher verbal immediacy and nonverbal immediacy scales are significantly correlated with each other. It is also revealed from correlational analysis that there exists a positive strong relationship in university students' motivation and their perception of teachers' verbal, nonverbal, and overall immediacy as $r=.626, p<.01 ; r=.677, p$ $<.01 ; r=.723, p<.01$, respectively. Hence, the null hypothesis "there is no relationship between students' perceived teacher immediacy and motivation" was rejected as the $p$ was less than .01 .

\section{DISCUSSION}

This study was proposed to examine the gender-based and sector-wise difference in university students' perceived teacher immediacy, and their motivation, and to explore the relationship between teacher immediacy and students' motivation. Several results drawn from analyzed data. First, according to participants' 
responses, their teachers exhibited moderately high both verbal and non-verbal immediacy behaviors in the classroom, nevertheless, students perceived nonverbal immediacy behaviors to be exhibited more often as compared to verbal immediacy behaviors. Velez and Cano (2008), and Estepp and Roberts (2015) found similar kind of results that teachers' exhibited higher non-verbal immediacy behaviors as compared to verbal immediacy behaviors. Estepp and Roberts (2015) also assumed that gesturing while talking, smiling at students, and looking at students while talking behaviors might be easier for teachers to exhibit than verbal immediacy behaviors, such as praising students work, calling students by name, and using personal examples, etc. Moreover, Wilson et al., (2010) concluded that teachers' verbal and non-verbal immediacy behaviors play a role in students' cognitive and affective development. However, Meyer (2009) considered that teachers who exhibit more immediacy behaviors can foster effective learning among students than those who exhibit less immediacy behaviors. Second, results also showed a vastly significant correlation between verbal immediacy and nonverbal immediacy of teachers. These results confirmed the findings of Edwards and Edwards (2001), and Velez and Cano (2008). These researchers found that there was a strong positive relationship between verbal and non-verbal behaviors of a person.

Third, students are motivated from their teachers' immediacy behaviors. Eccles and Wigfield (2002) found that teacher immediacy behaviors contribute to their students' interest and future value. However, Zusho (2017) concluded that reactions toward an instructor can affect students' interest in and value toward a course. Students answer better to teachers who smile (Richmond et al., 2007). Hence, student-teacher relationship can be improved by smiling. A smile is the best bridge to communicate with students. Results regarding the gender-based and sector-wise difference of university students' perceived teacher immediacy and their motivation showed an insignificant difference. These findings are in line with the conclusions reached by Paul et al. (2019) and $\mathrm{Yu}$ (2011). They concluded that there was no statistically significant gender-wise difference in perceived teachers both verbal and non-verbal immediacy behaviors. Lastly, correlational findings confirm the findings of previous research studies that a strong relationship between verbal, nonverbal, and overall teacher immediacy and students' motivation exists (Chesebro \& McCroskey, 2001; Fallah, 2014; Fernandes, 2019; Khan et al., 2015; MacIntyre et al., 2002; Menzel \& Carrell, 1999; Ozmen, 2011; Paul et al., 2019; Rocca, 2008; Witt \& Wheeless, 2001). Correspondingly, Velez and Cano (2008) concluded a moderate positive correlation between teacher immediacy and students' motivation, however, a study conducted by Ellis (2004) indicated no significant correlation between teachers' nonverbal immediacy and students' motivation. While Hsu (2010) determined a significant positive relationship between teachers' nonverbal immediacy and students' motivation. He suggested that nonverbal immediacy behaviors are significant predictors of students' motivation. Numerous other investigators found that teachers' verbal immediacy seems to have an impact on learners' motivation (Allen et al., 2006; Lin, 2003; Roberts \& Friedman, 2013).On the other hand, Johnson and Miller (2002), and Roach and Byrne (2001) believed that nonverbal immediacy behaviors have an impact on students' affective learning that varied from culture to culture. The reason behind the diverse results may be the methodological variance in studies.

\section{CONCLUSION}

Many investigators found that an effective teacher has a significant role in improving students' learning (Kristmanson, 2000; Levine, 2003; Li, 2003; Myers et al., 2002). Moreover, a student's attitudes and motivation are also influenced by the perceived immediacy behaviors of teachers (Allen et al., 2006). Therefore, the present study aimed to explore gender-based and sector-wise perceived teacher immediacy of university students and to examine the relationship in verbal, nonverbal, overall teachers' immediacy and students' motivation. Based on the analysis, researchers concluded no significant difference in male and female students' perceived teacher immediacy and their motivation level. In addition, researchers also found no significant difference in 
public and private university students' perceived teacher immediacy and motivation. However, students enrolled in private sector universities considered that their teachers exhibit more immediacy behaviors than perceived by students enrolled in public sector universities. Nevertheless, students enrolled in public-sector universities are more motivated than private-sector university students. It is also concluded from results that there was a strong positive significant relationship in verbal, nonverbal, and overall teacher immediacy and student motivation. Hence, it is determined that teacher immediacy behaviors influence student learning.

\section{RECOMMENDATIONS}

1. Teacher's immediacy behaviors influence the student-teacher relationship. Therefore, teachers may use different types of communication (verbal and nonverbal immediacy) while delivering a lesson in a classroom because these behaviors have a positive effect on their learners' motivation.

2. The educational institutes should plan different activities, i.e. seminars, pre-service, in-service training, workshops, etc., regularly, that are suitable to increase awareness among teachers regarding their immediacy behaviors because these behaviors can be helpful for students' learning.

3. It is suggested that content regarding teacher immediacy behaviors may be added in teacher training institutes' curricula for teacher training because it may be helpful for teachers to learn how they can communicate with learners and how they can enhance the student-teacher and peer relationship so learners become more motivated to learn.

4. In the future, investigators need to explore students' motivation as well as teacher immediacy behaviors through various learning environments (e.g.; virtual environment, e-learning environment, etc.) and to investigate the effects of teacher immediacy behaviors on students' cognitive and affective learning, etc.

5. The alternate method should be used to explore the immediacy behaviors of teachers and their students' enablers to learning. Data may be collected via teacher rating and self-report by students about the effective use of immediacy behaviors in the classroom.
6. Teacher immediacy and motivation are closely tied and worthy constructs of research. Therefore, for students' effective learning, researchers and psychologists should further explore the immediacy effects on students' motivation.

\section{References}

[1]. Allen, M., Witt, P. L., \& Wheeless, L. R. (2006). The role of teacher immediacy as a motivational factor in student learning: Using meta-analysis to test a causal model. Communication Education, 55(1), 21-31.

https://doi.org/10.1080/036345205003433 $\underline{68}$

[2]. Andersen, J. F. (1978). The relationship between teacher immediacy and teaching effectiveness [Unpublished doctoral dissertation, West Virginia University]. Morgantown.

[3]. Andersen, J. F. (1979). Teacher immediacy as a predictor of teaching effectiveness. In D. Nimmo (Eds.), Communication yearbook 3 (pp. 543-559). New Brunswick, NJ: Transaction Books.

[4]. Andersen, J. F., Andersen, P. A., \& Jensen, A. D. (1979). The measurement of nonverbal immediacy. Journal of Applied Communication Research, 7(2), 153-180. https://doi.org/10.1080/009098879093652 $\underline{04}$

[5]. Breed, G. R. (1971). Nonverbal communication and interpersonal attraction in dyads [Unpublished doctoral dissertation, University of Florida]. Retrieved from https://www.elibrary.ru/item.asp?id=6976 $\underline{026}$

[6]. Brophy, J. (2004). Motivating students to learn ( $2^{\text {nd }}$ ed.). Mahwah, New Jersey: Lawrence Erlbaum.

[7]. Butland, M. J., \& Beebe, S. A. (1992). Teacher immediacy and power in the 
classroom: The application of implicit communication theory. Paper presented at the Annual Meeting of the International Communication Association, Miami, FL.

[8]. Chesebro, J. L., \& McCroskey, J. C. (2001). The relationship of teacher clarity and immediacy with student state receiver apprehension, affect, and cognitive learning. Communication

Education, 50(1), 59-68. https://doi.org/10.1080/036345201093792 $\underline{32}$

[9]. Christensen, L. J., Curley, K. E., Marquez, E. M., \& Menzel, K. E. (1995). Classroom situations which lead to student participation. Paper presented at the 83rd annual meeting of the Speech Communication Association, San Antonio, TX.

[10]. Christophel, D. M. (1990). The relationships among teacher immediacy behaviors, student motivation, and learning. Communication

Education, 39(4), 323-340. https://doi.org/10.1080/036345290093788 $\underline{13}$

[11]. Deci, E. L., Vallerand, R. J., Pelletier, L. G., \& Ryan, R. M. (1991). Motivation and education: The self-determination perspective. Educational

Psychologist, 26(3-4), 325-346. https://doi.org/10.1080/00461520.1991.96 53137

[12]. Eccles, J. S., \& Wigfield, A. (2002). Motivational beliefs, values, and goals. Annual Review of Psychology, 53(1), 109-132.

[13]. Edwards, A., \& Edwards, C. (2001). The impact of instructor verbal and nonverbal immediacy on student perceptions of attractiveness and homophily. Journal of Excellence in College Teaching, 12(2), 5-
17.

Retrieved

from

http://celt.miamioh.edu/ject/

[14]. Ellis, K. (2004). The impact of perceived teacher confirmation on receiver apprehension, motivation, and learning. Communication

Education, 53(1),

https://doi.org/10.1080/036345203200013 $\underline{5742}$

[15]. Estepp, C. M., \& Roberts, T. G. (2015). Teacher immediacy and professor/student rapport as predictors of motivation and engagement. North American Colleges and Teachers of Agriculture, 59(2), 155-163. https://www.jstor.org/stable/nactajournal.59. $\underline{2.155}$

[16]. Fallah, N. (2014). Willingness to communicate in English, communication self-confidence, motivation, shyness, and teacher immediacy among Iranian Englishmajor undergraduates: A structural equation modeling approach. Learning and Individual Differences, 30(2), 140-147. https://doi.org/10.1016/j.lindif.2013.12.00 6

[17]. Fernandes, C. (2019). The relationship between teacher communication, and teacher credibility, student motivation, and academic achievement in India [Unpublished doctoral dissertation, Concordia University, St. Paul]. CUP ED.D. Dissertations. https://digitalcommons.csp.edu/cup_comm ons_grad_edd $/ 243$

[18]. Frymier, A. B., \& Houser, M. L. (2000). The teacher-student relationship as an interpersonal relationship. Communication Education, 49(3), 207-219. https://doi.org/10.1080/036345200093792 $\underline{09}$

[19]. Gorham, J. (1988). The relationship between verbal teacher immediacy behaviors and student 
learning. Communication

Education, 37(1),

40-53.

https://doi.org/10.1080/036345288093787

$\underline{02}$

[20]. Hines, C. V., Cruickshank, D. R., \& Kennedy, J. J. (1985). Teacher clarity and its relationship to student achievement and satisfaction. American Educational Research Journal, 22(1), 87-99. https://doi.org/10.3102/000283120220010 $\underline{87}$

[21]. Hofer, B. K. (2006). Motivation in the College Classroom. In W. J. McKeachie \& M. Svinicki (Eds.). McKeachie's teaching tips: Strategies, research, and theory for college and university teachers (pp. 140150). Boston: Houghton Mifflin.

[22]. Hsu, L. (2010). The impact of perceived teachers' nonverbal immediacy on students' motivation for learning English. Asian EFL Journal, 12(4), 188204. Retrieved from https://www.asian-efljournal.com

[23]. Johnson, S., \& Miller, A. (2002). A crosscultural study of immediacy, credibility, and learning in the US and Kenya. Communication Education, 51(3), 280-292.

https://doi.org/10.1080/03634520216514

[24]. Khan, S., Shah, A., \& Ahmad, S. (2015). The Role of Out-of-Class Communication in Instructor's Verbal/Non-Verbal Behavior, Trust, and Student Motivation. Business \& Economic Review,7(1), 81-100. Retrieved from http://bereview.pk/index.php/BER/index

[25]. Kleinfeld, J. S. (1973). Effects of nonverbally communicated personal warmth on the intelligence test performance of Indian and Eskimo adolescents. The Journal of Social Psychology, 91(1), 149-150. https://doi.org/10.1080/00224545.1973.99 $\underline{22656}$

[26]. Kristmanson, P. (2000). Affect: in the Second Language Classroom: How to create an emotional climate. Reflexions, 19(2), 1-5.

[27]. Levine, G. S. (2003). Student and instructor beliefs and attitudes about target language use, first language use, and anxiety: Report of a questionnaire study. The Modern Language Journal, 87(3), 343-364. https://doi.org/10.1111/1540-4781.00194

[28]. Li, L. T. (2003). Carl Rogers and Me: Revisiting Teaching. Thinking Classroom, 4(2), 34-42. (ERIC Document Reproduction Service No. EJ672739)

[29]. Lin, S. C. (2003). The relationship between teacher immediacy and students" willingness to communicate in English: An EFL context in Taiwan [Unpublished master's thesis, National Normal University]. D http://rportal.lib.ntnu.edu.tw/handle/20.500 $.12235 / 11945$

[30]. MacIntyre, P. D., Baker, S. C., Clément, R., \& Donovan, L. A. (2002). Sex and age effects on willingness to communicate, anxiety, perceived competence, and L2 motivation among junior high school French immersion students. Language Learning, 52(3),

537-564. https://doi.org/10.1111/1467-9922.00194

[31]. McCroskey, J. C., Sallinen, A., Fayer, J. M., Richmond, V. P., \& Barraclough, R. A. (1996). Nonverbal immediacy and cognitive learning: A cross-cultural investigation. Communication

Education, 45(3), 200-211. https://doi.org/10.1080/036345296093790 49

[32]. Mehrabian, A. (1968). Some referents and measures of nonverbal behavior. Behavior Research Methods \& 
Instrumentation, 1(6),

203-207.

https://doi.org/10.3758/BF03208096

[33]. Mehrabian, A. (1971). Verbal and nonverbal interaction of strangers in a waiting situation. Journal of Experimental Research in Personality, 5(2), 127-138. Retrieved from https://psycnet.apa.org/record/197220869-001

[34]. Mehrabian, A. (1981). Silent messages: Implicit communication of emotions and attitudes $\quad\left(2^{\text {nd }}\right.$ ed.). Belmont, CA: Wadsworth.

[35]. Menzel, K. E., \& Carrell, L. J. (1999). The impact of gender and immediacy on willingness to talk and perceived learning. Communication

Education, 48(1), 31-40. https://doi.org/10.1080/036345299093791 $\underline{50}$

[36]. Menzel, K. E., \& Carrell, L. J. (1999). The impact of gender and immediacy on willingness to talk and perceived learning. Communication

Education, 48(1), 31-40. https://doi.org/10.1080/036345299093791 $\underline{50}$

[37]. Meyers, S. A. (2009). Do your students care whether you care about them?. College Teaching, 57(4), 205-210. https://doi.org/10.1080/875675509032186 $\underline{20}$

[38]. Myers, S., Martin, M., \& Mottet, T. (2002). Students' motives for communicating with their instructors: Considering instructor socio-communicative style, student sociocommunicative orientation, and student gender. Communication Education, 51(2), 121-133.

https://doi.org/10.1080/03634520216511

[39]. Özmen, K. S. (2011). Perception of Nonverbal Immediacy and Effective Teaching among Student Teachers: A
Study across $\quad$ Cultural

Extremes. International Online Journal of Educational Sciences, 3(3), 865-881. Retrieved from https://iojes.net/

[40]. Paul, A., Maiti, N. C., Nath, I. (2019). Nonverbal immediacy behaviour and teacher effectiveness in secondary schools of West Bengal. Education Quarterly Reviews, 2(1), 33-40. https://doi.org/10.31014/aior.1993.02.01.3 6

[41]. Plax, T. G., Kearney, P., McCroskey, J. C., \& Richmond, V. P. (1986). Power in the classroom VI: Verbal control strategies, nonverbal immediacy and affective learning. Communication Education, 35(1), 43-55. https://doi.org/10.1080/036345286093883 $\underline{18}$

[42]. Pogue, L. L., \& AhYun, K. (2006). The effect of teacher nonverbal immediacy and credibility on student motivation and affective learning. Communication Education, 55(3), 331-344. https://doi.org/10.1080/036345206007486 23

[43]. Powell, R. G., \& Harville, B. (1990). The effects of teacher immediacy and clarity on instructional outcomes: An intercultural assessment. Communication

Education, 39(4), 369-379. https://doi.org/10.1080/036345290093788 $\underline{16}$

[44]. Richmond, V. P., \& McCroskey, J. C., \& Hickson, M. L. (2007). Nonverbal behavior in Interpersonal relations ( $6^{\text {th }}$ ed.). Boston, MA: Allyn and Bacon.

[45]. Richmond, V. P., Gorham, J. S., \& McCroskey, J. C. (1987). The relationship between selected immediacy behaviors and cognitive learning. Annals of the International Communication Association, 10(1), 574-590.

www.psychologyandeducation.net 
https://doi.org/10.1080/23808985.1987.11 $\underline{678663}$

[46]. Roach, K. D., \& Byrne, P. R. (2001). A cross-cultural comparison of instructor communication in American and German classrooms. Communication

Education, 50(1), $1-14$. https://doi.org/10.1080/036345201093792 $\underline{28}$

[47]. Roberts, A., \& Friedman, D. (2013). The impact of teacher immediacy on student participation: An objective crossdisciplinary examination. International Journal of Teaching and Learning in Higher Education, 25(1), 38-46. Retrieved from http://www.isetl.org/ijtlhe

[48]. Rocca, K. A. (2008). Participation in the college classroom: The impact of instructor immediacy and verbal aggression. The Journal of Classroom Interaction, 43(2), 22-33.

\section{https://www.jstor.org/stable/23869675}

[49]. Rodríguez, J. I., Plax, T. G., \& Kearney, P. (1996). Clarifying the relationship between teacher nonverbal immediacy and student cognitive learning: Affective learning as the central causal mediator. Communication

Education, 45(4), 293-305. https://doi.org/10.1080/036345296093790 $\underline{59}$

[50]. Rubin, R. B., Palmgreen, P., \& Sypher, H. E. (1994). Communication research measures: A sourcebook. New York, NY: The Guilford Press.

[51]. Velez, J. J., \& Cano, J. (2008). The relationship between teacher immediacy and student motivation. Journal of Agricultural Education, 49(3), 76-86. https://doi.org/10.5032/jae.2008.03076

[52]. Wigfield, A., \& Eccles, J. S. (2000). Expectancy-value theory of achievement motivation. Contemporary Educational
Psychology, 25(1),

68-81.

https://doi.org/10.1006/ceps.1999.1015

[53]. Wilson, J. H., Ryan, R. G., \& Pugh, J. L. (2010). Professor-student rapport scale predicts student outcomes. Teaching of Psychology, 37(4),

246-251. https://doi.org/10.1080/00986283.2010.51 0976

[54]. Witt, P. L., \& Wheeless, L. R. (2001). An experimental study of teachers' verbal and nonverbal immediacy and students' affective and cognitive learning. Communication Education, 50(4), 327-342. https://doi.org/10.1080/036345201093792 $\underline{59}$

[55]. Witt, P. L., Wheeless, L. R., \& Allen, M. (2004). A meta-analytical review of the relationship between teacher immediacy and student learning. Communication Monographs, 71(2),

184-207. https://doi.org/10.1080/036452042000228 $\underline{054}$

[56]. Woolfolk, A. E. (1978). Student learning and performance under varying conditions of teacher verbal and nonverbal evaluative communication. Journal of Educational Psychology, 70(1), 87-94. Retrieved from http://pascal-

francis.inist.fr/vibad/index.php?action=get $\underline{\text { RecordDetail\&idt }=12737279}$

[57]. Yu, M. (2011). Effect of communication variables, affective variables, and teacher immediacy on willingness to communicate of foreign language learners. Chinese Journal of Communication, 4(2), 218-236. https://doi.org/10.1080/17544750.2011.56 $\underline{5678}$

[58]. Zusho, A. (2017). Toward an integrated model of student learning in the college classroom. Educational Psychology Review, 29(2), 
https://doi.org/10.1007/s10648-017-9408-

$\underline{4}$ 